\title{
ECOMORPHOLOGY AND FOOD HABITS OF TELEOST FISHES Trachinotus carolinus (TELEOSTEI: CARANGIDAE) AND Menticirrhus littoralis (TELEOSTEI: SCIAENIDAE), INHABITING THE SURF ZONE OFF NITERÓI, RIO DE JANEIRO, BRAZIL*
}

\author{
Luana Prestrelo Palmeira ${ }^{* *}$ and Cassiano Monteiro-Neto
}

Universidade Federal Fluminense

Departamento de Biologia Marinha

(Outeiro de São João Batista s/n, Caixa Postal 100644, 24.001-970 Niterói, RJ, Brasil)

**E-mail: luapres@yahoo.com.br

\section{A B S TR ACT}

The ecomorphology and food habits of juvenile Trachinotus carolinus and Menticirrhus littoralis caught in the surf zone of sandy beaches in Niterói, RJ, were investigated between July 2006 and May 2007. These fish species differ morphologically, but present similarities in their diet composition suggest some slight overlapping in their diet. The importance of food items was assessed using Kawakami and Vazzoler's feeding index. Morphometric variables were recorded to correlate with the diet composition of the different size classes for each species. A total of 210 fishes (Trachinotus carolinus - 122, Menticirrhus littoralis - 88), ranging between $24.2 \mathrm{~mm}$ and $112 \mathrm{~mm}$ total length, were analyzed, but the stomachs of only $84.8 \%$ of them contained food. Trachinotus carolinus presented mysids, Polychaetes and Emerita spp. as the predominant items in their diet. Formicidae and Isopoda were the most important items for class I individuals, whereas mysids and Emerita spp. were important for classes II and III. Class I individuals also showed smaller sized prey (amphipods and isopods) and clupeid fish larvae in their diet. Emerita spp. dominated the food items of Menticirrhus littoralis regardless of the size class. Polychaetes, the second most important item was better represented in class sizes II and III. The main morphometric variable correlated with such differences included mouth position and diameter of the eye.

\section{R ESUMO}

A ecomorfologia e os hábitos alimentares de juvenis de Trachinotus carolinus e Menticirrhus littoralis capturados na zona de arrebentação de praias arenosas em Niterói, RJ, foram investigados entre julho de 2006 e Maio de 2007. Ambas as espécies diferem morfologicamente, mas apresentam semelhanças em sua dieta, sugerindo uma possível sobreposição alimentar. A importância dos itens alimentares foi avaliada utilizando o índice alimentar de Kawakami e Vazzoler. Variáveis morfométricas foram correlacionadas à dieta observada para diferentes classes de tamanho, para cada espécie. Um total de 210 peixes (Trachinotus carolinus - 122, Menticirrhus littoralis - 88), variando entre $24.2 \mathrm{~mm}$ e $112 \mathrm{~mm}$ de comprimento total, foram analisados, mas apenas $84.8 \%$ continham alimento. Trachinotus carolinus apresentou mysidáceos, poliquetas e Emerita spp. como os itens predominantes na dieta. Formicidae e Isopoda foram os itens mais importantes para a classe I de tamanho dos indivíduos, enquanto que mysidáceos e Emerita spp. foram importantes para as classes II e III. Indivíduos da classe I também apresentaram itens de menor tamanho (anfípodos e isópodos) bem como larvas de peixes clupeídeos na dieta. Emerita spp. dominou a alimentação de Menticirrhus littoralis, independentemente da classe de tamanho. Poliquetas, o segundo item mais importante, foi mais bem representado na classe II e III de tamanho dos indivíduos. As principais variáveis morfométricas correlacionadas com essas diferenças incluíram a posição da boca e o diâmetro do olho.

Descriptors: Diet, Surf zone, Morphometric analysis, Carangidae, Sciaenidae

Descritores: Dieta, Zona de arrebentação, Análise morfométrica, Carangidae, Sciaenidae.

\section{INTRODUCTION}

Ecomorphology aims to establish a correlation between one or several morphological features, which would indicate a potential adaptation

(*) Paper presented at the $2^{\text {nd }}$ Brazilian Congress of Marine Biology, on 24-28 May. Búzios, RJ, Brazil. 2009. of a particular species to a certain ecological niche (COSTA; CATAUDELLA, 2007; TEIXEIRA; BENNEMANN, 2007). Thus, one may determine which environmental or biological factors are influencing individual forms within an ecosystem, thus increasing their success in the exploitation of the available resources (MOTTA; KOTRSCHALL, 1992; CUNICO; AGOSTINHO, 2006). 
Ecomorphology is an appropriate method for describing species ecology, including food preferences, diet overlap, and habitat use (TEIXEIRA; BENNEMANN, 2007). Fish diet studies provide the baseline data for the trophic organization of ecosystems, whereas feeding performance links fish morphology and diet (MOTTA; KOTRSCHALL, 1992), providing the tool for understanding the species' roles within fish communities. Thus, studies based on analysis of stomach contents are one of the few resources that can provide information on feeding ecology and many studies of stomach contents have, therefore, been made (e.g. MOTTA et al., 1995; AMUNDSEN et al. 1996; DELARIVA; AGOSTINHO 2001; CASATTI et al., 2005; TEIXEIRA; BENNEMANN, 2007).

Trachinotus carolinus is widely distributed in the western Atlantic from Massachusetts (EUA) to southeastern Brazil (FIGUEIREDO; MENEZES, 1980), with its young usually inhabiting the nearshore and surf zone habitats (MIGDALSK; FICHER, 1976; MONTEIRO-NETO et al., 2003). Menticirrhus littoralis (Teleostei, Sciaenidae) is also found near the coast within the $21 \mathrm{~m}$ isobath from southern Florida to southern Brazil (FIGUEIREDO; MENEZES, 1980), with juveniles frequently occupying the surf zone of sandy beaches (MONTEIRO-NETO et al., 2003). Studies have shown that the young of both species present great site fidelity, and often rank within the most abundant species in the surf zone (SALOMAN; NAUGHTON, 1979; MODDE, 1980; MODDE; ROSS, 1981; PETERS; NELSON, 1986; ROSS et al., 1987; ROSS; LANCASTER, 2002; MONTEIRONETO et. al., 2003; 2008; VASCONCELLOS et al., 2007). Despite their distinct morphology, food habit analysis of Trachinotus and Menticirrhus genera indicated a diet based on benthic organisms, especially small crustaceans (BELLINGER; AVAUT, 1971; NELSON, 1986; ROSS; MCMICHAEL, 1987; MONTEIRO-NETO; CUNHA, 1990; HELMER et al., 1995; WHEELER et al., 2002; BATISTIC et al., 2005), suggesting a possible diet overlap within their first year in the surf zone.

The present study addresses this hypothesis by qualifying and quantifying the diet of $T$. carolinus and $M$. littoralis, within the surf zone of several sandy beaches in Niterói, Rio de Janeiro, Brazil, describing the species' morphological characteristics most closely related to their feeding habits, and establishing the possible ecomorphological relationships.

\section{Material And Methods}

We collected fishes at eight different beach localities (Flexas, Icarai, São Francisco, Charitas, Adão, Eva, Forte, Imbuí) on the eastern margin and near the mouth of Guanabara Bay, Niterói, Rio de Janeiro (Fig. 1), monthly between July 2006 and May 2007. All the collections were conducted in the morning, from 8:00 to 12:00. We used a $16 \mathrm{~m}$ length beach seine with $2.5 \mathrm{~m}$ height and $10 \mathrm{~mm}$ mesh to collect the fish. The seine was hauled parallel to the shore for $20 \mathrm{~m}$ at depths ranging between $0.5 \mathrm{~m}$ and 1 $\mathrm{m}$ deep. Samples were cooled on ice and then fixed in $10 \%$ formalin in the laboratory. The two species were then separated, identified (FIGUEIREDO; MENEZES, 1980) and preserved in $70 \%$ alcohol for further study.

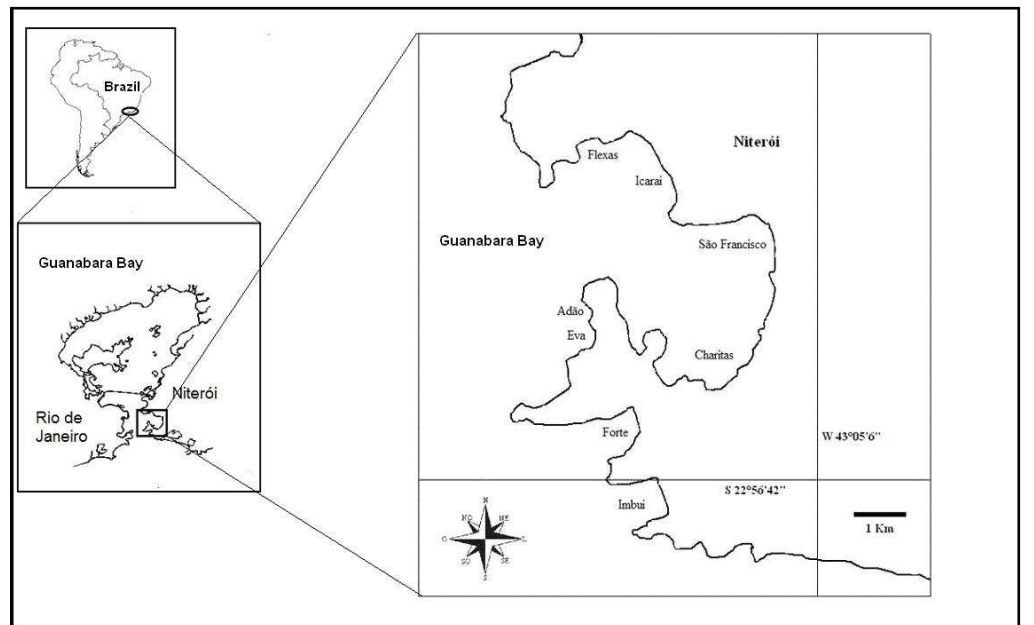

Fig. 1: Study area. On the left, South America and Brazil, the State of Rio de Janeiro being located within the circle; below, the full extent of Guanabara Bay, highlighting the study region; on the right, the data collection sites giving the names of the beaches sampled and their coordinates. 
Individuals were weighed and the stomach and intestine removed for food analysis. Stomachs were weighed separately to calculate fullness index $\left(\mathrm{IR}=\mathrm{W}_{\mathrm{e}} / \mathrm{W}_{\mathrm{t}} \times 100\right.$, where $\mathrm{W}_{\mathrm{e}}=$ stomach weight and $\mathrm{W}_{\mathrm{t}}=$ total weight). Results were expresssed as average IR within the size classes of each species. Stomachs were dissected, contents washed over a Petri dish and observed under a stereomicroscope for identification. All items were weighed on a precision scale $(0.001 \mathrm{~g})$. The importance of each food item was analyzed based on its frequency of occurrence and weight, and with the application of the feeding index $\left(\mathrm{FI}_{\mathrm{i}}=\mathrm{F}_{\mathrm{i}} \mathrm{V}_{\mathrm{i}}\right.$ / $\sum\left(F_{i} V_{i}\right)$, where $\mathrm{FI}_{\mathrm{i}}=$ feeding index of the $\mathrm{i}^{\text {th }}$ food item, $\mathrm{F}_{\mathrm{i}}=$ percentage frequency of occurrence, and $\mathrm{V}_{\mathrm{i}}=$ percentage volume) proposed by KAWAKAMI and VAZZOLER (1980), replacing the percentage volume by percentage weight in all items.

The following morphometric measurements were taken $(0.01 \mathrm{~mm})$, in accordance with previous definitions (CAILLIET et al., 1986; SCHAFER et al., 2002; WARD-CAMPBELL et al., 2005; FERREIRA 2007; TEIXEIRA; BENNEMANN, 2007): (a) standard length (SL); (b) maximum height (MH); (c) maximum width (MW); (d) length of the caudal peduncle (LCP); (e) height of the caudal peduncle (HCP); (f) width of the caudal peduncle (WCP); (g) height of the body below the lateral line (HBL); (h) head length (HL); (i) head height (HH); (j) position of the eye (PE); (k) diameter of the eye (DE); (l) mouth position (MOP); (m) mouth width (MOW); (n) mouth height (MOH); (o) nose closed length (NCL); (p) nose open length (NOL); (q) dorsal fin height (DFH); (r) dorsal fin length (DFL); (s) pectoral fin length (PFL); (t) pectoral fin height $(\mathrm{PFH})$; (u) caudal fin length (CFL); (v) caudal fin height (CFH); (w) pelvic fin length (PEL); (x) anal fin height (ANH), and (y) anal fin length (ANL).

To verify possible ontogenetic changes in food habits within the size range of individuals collected, three size groups were defined for either of the two species: I $(T$. carolinus $<45.1 \mathrm{~mm} ; M$. littoralis $<55.1 \mathrm{~mm})$, II $(45.1 \mathrm{~mm} \leq T$. carolinus $\leq$

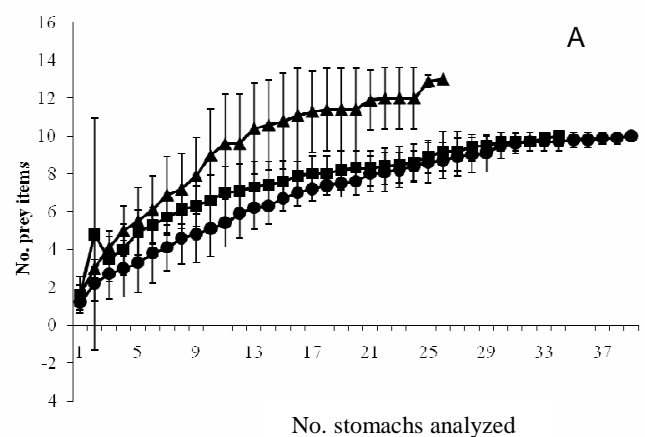

$70.0 \mathrm{~mm} ; 55.1 \mathrm{~mm} \leq M$ littoralis $\leq 65.0 \mathrm{~mm}$ ) and $\mathrm{III}$ (T. carolinus $\geq 71.1 \mathrm{~mm} ;$ M littoralis $\geq 65.1 \mathrm{~mm}$ ).

A cumulative prey curve was constructed for each size class of the two species to ascertain whether an appropriate number of stomachs had been analyzed for an accurate characterization of the diets. The order in which the stomachs were analyzed was randomized ten times and the mean number of new prey found consecutively in the stomachs was plotted against numbers of stomachs analyzed (in accordance with FERRY et. al, 1997).

Principal Component Analysis (PCA) was applied to explore the relationship between size class and food item within the species. The relationship between predominant food items for different size classes of each species, and the morphometric variables recorded were investigated by Canonical Correspondence Analysis (CCA) (LEGENDRE; LEGENDRE, 1998). The primary matrix consisted of the feeding index of food items (row) per size class of each species (column), and the secondary matrix consisted of morphometric variables 'a' to ' $y$ '. This analysis was carried out exclusively on CANOCO by Windows 4.0 (TER BRAAK; SMILAUER, 1998).

\section{RESULTS}

A total of 210 fishes (T. carolinus $-122, M$. littoralis - 88), ranging between $24.2 \mathrm{~mm}$ and 112.0 $\mathrm{mm}$ total length, were analyzed. One hundred and seventy-eight stomachs $(84.8 \%)$ presented food contents, whereas thirty-two $(15.2 \%)$ were empty. For size classes I, II and III of T. carolinus 34, 39 and 26 were analyzed and of $M$. littoralis 24,31 and 24 , respectively.

Cumulative prey curves showed a rapid approach to an asymptote mainly for M. littoralis and $T$. carolinus sizes I and II, suggesting that for these species a sufficient number of stomach were analyzed. For size III of the two species the curve reached an asymptote slowly, since new prey items constantly appeared in the diet of the biggest individuals (Fig. 2).

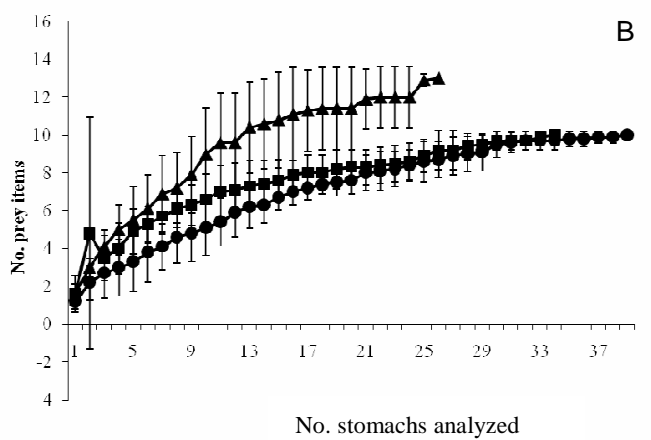

Fig. 2. Cumulative prey curves for: a) Trachinotus carolinus $(\mathrm{n}=99)$, and b) Menticirrhus littoralis $(\mathrm{n}=79)$. Symbols are: square for size class I $(\mathrm{n}=34$ for $T$. carolinus and 24 for $M$. littoralis), circle for size class II ( $\mathrm{n}=39$ for $T$. carolinus and 31 for M. littoralis), and triangle for size class III ( $\mathrm{n}=26$ for $T$. carolinus and 24 for M. littoralis). 
Average fullness index ranged between two and three percent, with highest averages occurring in size class I for $T$. carolinus $(3.2 \%)$ and II for $M$. littoralis $(3.0 \%)$. Size class III individuals showed the lowest averages around 2.3 for $T$. carolinus and 2.5 for M. littoralis (Fig. 3)

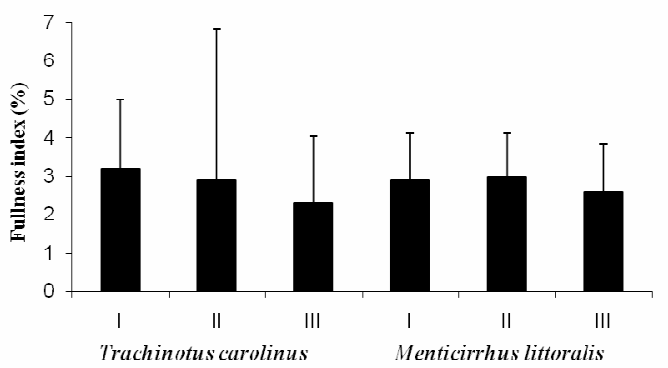

Fig. 3. Mean and standard deviation of the fullness index by size class of Trachinotus carolinus and Menticirrhus littoralis.
Table 1 shows the average of morphometric measurements by size class for each species, whereas Table 2 shows food items arranged in phylogenetic order and Kawakami and Vazoller's feeding index by size class for each species. T. carolinus showed mysids, Emerita spp. and polychaetes as the predominant items in the diet, whereas Emerita spp. dominated the food items of $M$. littoralis, followed by polychaetes.

Principal Component Analysis showed that the feeding of size class I T. carolinus was strongly influenced by Isopoda, Formicidae and Amphipoda. Size class II shared Emerita spp. and mysids with size class III. Class III showed the greatest diversity of food items, including Emerita spp. and Mytilidae (Fig. 4a). Size class I M. littoralis showed an association with amphipods, unidentified crustacean remains and mysids. Nematods were associated with size class II individuals and Formicidae, Decapoda, Mytilidae and copepods with size class III. Emerita spp., present in all classes, showed no association with any particular size class of M. littoralis (Fig. 4b).

Table 1. Average \pm standard deviation of morphometric mesurements by size class of Trachinotus carolinus and Menticirrhus littoralis.

\begin{tabular}{|c|c|c|c|c|c|c|c|}
\hline \multirow[b]{2}{*}{ Morphometric Measures } & \multirow[b]{2}{*}{ Acronyms } & \multicolumn{3}{|c|}{ Trachinotus carolinus } & \multicolumn{3}{|c|}{ Menticirrhus littoralis } \\
\hline & & $\mathbf{I}$ & II & III & $\mathbf{I}$ & II & III \\
\hline Standard length & SL & $35.5 \pm 5.2$ & $59.4 \pm 7.6$ & $83.6 \pm 8.8$ & $45.4 \pm 6.7$ & $59.7 \pm 2.8$ & $75.3 \pm 11.2$ \\
\hline Maximum height & $\mathrm{MH}$ & $12.9 \pm 2.4$ & $23.2 \pm 3.7$ & $35.3 \pm 5.3$ & $9.0 \pm 1.5$ & $12.1 \pm 1.6$ & $15.7 \pm 2.7$ \\
\hline Maximum width & MW & $4.8 \pm 1.2$ & $8.8 \pm 1.5$ & $12.1 \pm 2.0$ & $6.3 \pm 1.2$ & $8.3 \pm 0.8$ & $11.3 \pm 2.3$ \\
\hline Length of the caudal peduncle & LCP & $2.9 \pm 0.8$ & $6.7 \pm 1.8$ & $9.7 \pm 1.8$ & $11.7 \pm 2.0$ & $15.8 \pm 1.4$ & $20.3 \pm 3.7$ \\
\hline Height of the caudal peduncle & $\mathrm{HCP}$ & $2.8 \pm 0.6$ & $4.9 \pm 0.7$ & $7.1 \pm 1.2$ & $3.8 \pm 0.6$ & $5.0 \pm 0.6$ & $6.6 \pm 1.2$ \\
\hline Width of the caudal peduncle & WCP & $0.5 \pm 0.2$ & $1.5 \pm 0.4$ & $2.8 \pm 1.6$ & $0.6 \pm 0.3$ & $1.1 \pm 0.4$ & $1.8 \pm 0.6$ \\
\hline $\begin{array}{l}\text { Height of the body below the } \\
\text { lateral line }\end{array}$ & HBL & $10.1 \pm 1.8$ & $17.4 \pm 2.8$ & $24.0 \pm 3.5$ & $7.4 \pm 1.4$ & $9.8 \pm 1.3$ & $12.5 \pm 2.1$ \\
\hline Head length & HL & $11.9 \pm 1.6$ & $18.3 \pm 2.6$ & $24.3 \pm 2.2$ & $14.2 \pm 2.1$ & $17.9 \pm 0.9$ & $22.3 \pm 3.7$ \\
\hline Head height & $\mathrm{HH}$ & $7.3 \pm 1.4$ & $12.5 \pm 2.0$ & $17.3 \pm 3.1$ & $6.5 \pm 1.0$ & $8.4 \pm 0.7$ & $10.6 \pm 1.8$ \\
\hline Position of the eye & $\mathrm{PE}$ & $4.1 \pm 1.0$ & $7.3 \pm 1.4$ & $9.6 \pm 1.4$ & $3.7 \pm 0.7$ & $5.2 \pm 0.7$ & $6.6 \pm 1.5$ \\
\hline Diameter of the eye & $\mathrm{DE}$ & $2.8 \pm 0.6$ & $4.6 \pm 0.6$ & $6.0 \pm 0.6$ & $2.7 \pm 0.6$ & $3.5 \pm 0.4$ & $4.1 \pm 0.6$ \\
\hline Mouth position & MOP & $1.0 \pm 0.0$ & $1.0 \pm 0.0$ & $1.0 \pm 0.0$ & $2.0 \pm 0.0$ & $2.0 \pm 0.0$ & $2.0 \pm 0.0$ \\
\hline Mouth width & MOW & $2.3 \pm 0.7$ & $4.4 \pm 1.0$ & $6.3 \pm 1.3$ & $2.6 \pm 0.7$ & $3.4 \pm 0.4$ & $4.2 \pm 1.1$ \\
\hline Mouth height & $\mathrm{MOH}$ & $4.6 \pm 0.7$ & $6.8 \pm 1.4$ & $8.6 \pm 2.1$ & $3.8 \pm 1.2$ & $4.9 \pm 1.0$ & $5.6 \pm 1.5$ \\
\hline Nose closed length & NCL & $3.7 \pm 0.6$ & $6.3 \pm 1.3$ & $8.7 \pm 1.0$ & $5.1 \pm 0.8$ & $6.6 \pm 0.5$ & $7.9 \pm 2.2$ \\
\hline Nose open length & NOL & $6.3 \pm 1.1$ & $10.1 \pm 1.8$ & $12.7 \pm 2.3$ & $6.6 \pm 1.0$ & $8.3 \pm 1.1$ & $10.2 \pm 2.9$ \\
\hline Dorsal fin height & DFH & $8.1 \pm 1.9$ & $14.4 \pm 3.0$ & $21.0 \pm 4.1$ & $9.7 \pm 1.4$ & $12.2 \pm 1.2$ & $16.2 \pm 3.1$ \\
\hline Dorsal fin length & DFL & $21.3 \pm 3.8$ & $34.6 \pm 5.8$ & $43.4 \pm 10.1$ & $27.7 \pm 3.7$ & $35.6 \pm 2.3$ & $45.4 \pm 8.2$ \\
\hline Pectoral fin length & PFL & $7.1 \pm 1.3$ & $12.4 \pm 2.0$ & $17.3 \pm 1.5$ & $8.0 \pm 1.5$ & $10.6 \pm 1.3$ & $13.6 \pm 3.9$ \\
\hline Pectoral fin height & PFH & $2.9 \pm 0.8$ & $5.5 \pm 1.4$ & $8.1 \pm 1.3$ & $2.1 \pm 0.6$ & $3.0 \pm 0.5$ & $4.2 \pm 1.4$ \\
\hline Caudal fin length & CFL & $10.8 \pm 1.9$ & $18.0 \pm 3.0$ & $24.0 \pm 6.5$ & $11.3 \pm 2.6$ & $14.8 \pm 1.8$ & $18.8 \pm 3.2$ \\
\hline Caudal fin height & $\mathrm{CFH}$ & $9.6 \pm 2.6$ & $15.7 \pm 4.6$ & $21.8 \pm 7.4$ & $4.7 \pm 1.4$ & $6.7 \pm 1.2$ & $9.0 \pm 2.3$ \\
\hline Pelvic fin length & PEL & $5.3 \pm 1.0$ & $8.8 \pm 1.5$ & $11.7 \pm 1.6$ & $8.2 \pm 1.3$ & $10.6 \pm 1.3$ & $13.9 \pm 2.3$ \\
\hline Anal fin height & ANH & $7.4 \pm 1.5$ & $12.9 \pm 2.6$ & $18.2 \pm 3.9$ & $9.3 \pm 1.6$ & $11.7 \pm 1.3$ & $14.6 \pm 2.3$ \\
\hline Anal fin length & ANL & $12.8 \pm 2.4$ & $22.2 \pm 3.7$ & $29.1 \pm 4.9$ & $5.1 \pm 0.8$ & $6.6 \pm 0.9$ & $8.3 \pm 1.5$ \\
\hline
\end{tabular}


Table 2. Feeding index of KAWAKAMI and VAZZOLER (1980) (X 100), of each food item by total length size class (I, II and II) of Trachinotus carolinus and Menticirrhus littoralis and the total feeding index value of each food item. Blank = $0 ; 0<0.0<0.1$.

\begin{tabular}{|c|c|c|c|c|c|c|c|c|c|}
\hline \multirow{2}{*}{ Food Items } & \multirow{2}{*}{ Acronyms } & \multicolumn{4}{|c|}{ Trachinotus carolinus } & \multicolumn{4}{|c|}{ Menticirrhus littoralis } \\
\hline & & I & II & III & Total & $\mathrm{I}$ & II & III & Total \\
\hline Nematoda & NEM & 0.0 & 0.0 & 0.0 & 0.0 & & 0.0 & 0.0 & 0.0 \\
\hline \multicolumn{10}{|l|}{ Mollusca } \\
\hline Mytilidae & MYT & & 0.1 & 0.8 & 0.3 & & & 0.0 & 0.0 \\
\hline \multicolumn{10}{|l|}{ Annelida } \\
\hline Polychaeta & POL & 55.0 & 8.1 & 23.5 & 23.8 & 4.9 & 11.7 & 20.8 & 14.1 \\
\hline \multicolumn{10}{|l|}{ Arthropoda } \\
\hline \multicolumn{10}{|l|}{ Hymenoptera } \\
\hline Formicidae & FOR & 4.8 & 0.0 & 0.0 & 0.3 & & & 0.0 & 0.0 \\
\hline Vespidae & VES & & & 0.0 & 0.0 & & & & \\
\hline Arachnida & ARA & & & & & & & 0.0 & 0.0 \\
\hline \multicolumn{10}{|l|}{ Crustacea } \\
\hline Amphipoda & AMP & 0.9 & 0.1 & 0.0 & 0.1 & 0.3 & 0.0 & 0.1 & 0.1 \\
\hline Decapoda & DEC & & & 0.0 & 0.0 & & & 0.1 & 0.0 \\
\hline Copepoda & $\mathrm{COP}$ & 0.0 & 0.0 & & 0.0 & & & 0.0 & 0.0 \\
\hline Cumacea & CUM & & & & & & & 0.0 & 0.0 \\
\hline Emerita sp. & EME & 6.2 & 3.7 & 20.7 & 9.8 & 91.1 & 88.2 & 76.0 & 84.7 \\
\hline Isopoda & ISO & 27.1 & 0.2 & & 1.4 & & 0.0 & 0.0 & 0.0 \\
\hline Mysidacea & MYS & 5.5 & 87.5 & 36.6 & 59.9 & 2.1 & 0.1 & 0.9 & 0.6 \\
\hline Larvae & LAR & & 0.0 & 0.0 & 0.0 & & & & \\
\hline Unidentified & UND & 0.1 & 0.1 & 18.3 & 4.2 & 1.5 & & 0.7 & 0.3 \\
\hline \multicolumn{10}{|l|}{ Teleostei } \\
\hline Clupeidae & CLU & 0.4 & 0.1 & 0.2 & 0.2 & & & 0.0 & 0.0 \\
\hline \multicolumn{10}{|l|}{$\begin{array}{l}\text { Unidentified } \\
\text { Contents }\end{array}$} \\
\hline Larvae & UNL & & 0.0 & & 0.0 & & & & \\
\hline Eggs & UNE & & & 0.0 & 0.0 & & & & \\
\hline Organisms & UNO & & & & & 0.0 & & 1.3 & 0.3 \\
\hline
\end{tabular}

a) Trachinotus carolinus

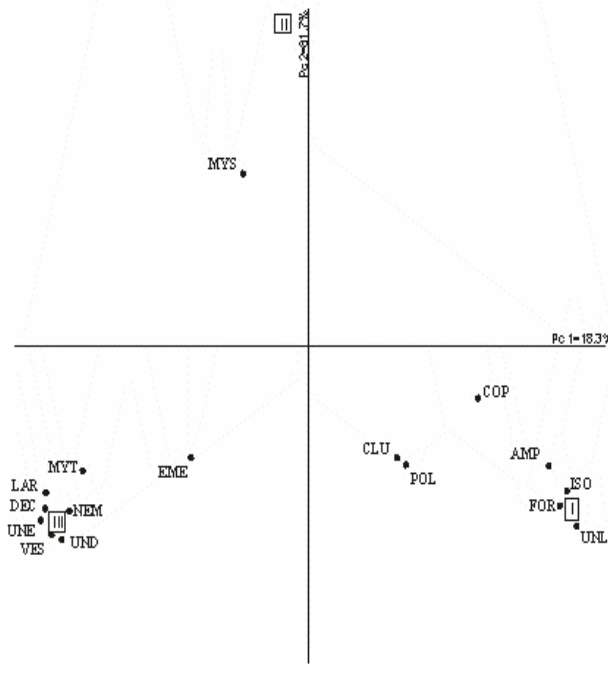

b) Menticirrhus littoralis

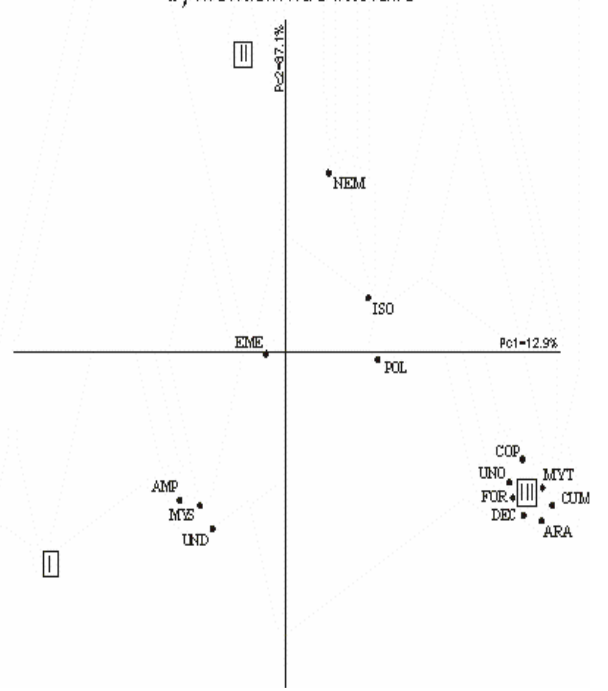

Fig. 4. Principal Component Analysis of food items and size class (I, II, III) of (a) Trachinotus carolinus and (b) Menticirrhus littoralis. 
Canonical Correlation Analysis indicated that mouth position was the most important morphometric variable discriminating feeding adaptation between the species. This morphometric characteristic is positively correlated with the diet of $M$. littoralis and negatively with that of $T$. carolinus. Also, eye diameter, nose open length and width of the caudal peduncle played an important role in explaining the differences observed (Fig. 5).

\section{Discussion}

The rapid attainment of an asymptote in the I and II size classes may be associated with the lesser variety of prey items in the diet of the smaller individuals. Thus the lack of an asymptote for the biggest size classes of the two species also suggests that the greater the diversity of food items, the larger must be the number of individuals analyzed, so there is a sufficient amount of data to characterize the diet of the individuals, as was also noticed by FERRY et. al (1997).

The diets of the two species were similar, consisting mostly of benthic organisms, especially of small crustaceans, as already described in the literature (BELLINGER; AVAUT, 1971; NELSON, 1986; ROSS; McMICHAEL, 1987; HELMER et al., 1995; WHEELER et al., 2002). The fullness index suggested that most active feeders lay in the size range of size class I for $T$. carolinus $(<45.1 \mathrm{~mm})$ and II for $M$. litoralis $(55.1-65.0 \mathrm{~mm})$, corroborating previous studies on Trachinotus (MONTEIRO-NETO; CUNHA, 1990) and Menticirrhus (LAMEIRO, 2003) species in the surf zone. Secondary diet patterns relating to size within species indicate an ontogenetic change in diet, especially in $T$. carolinus, as previously observed by other authors (McCORMICK, 1995; RUSSO et. al., 2007), including other species of Trachinotus (MONTEIRO-NETO; CUNHA, 1990, HELMER et al., 1995).

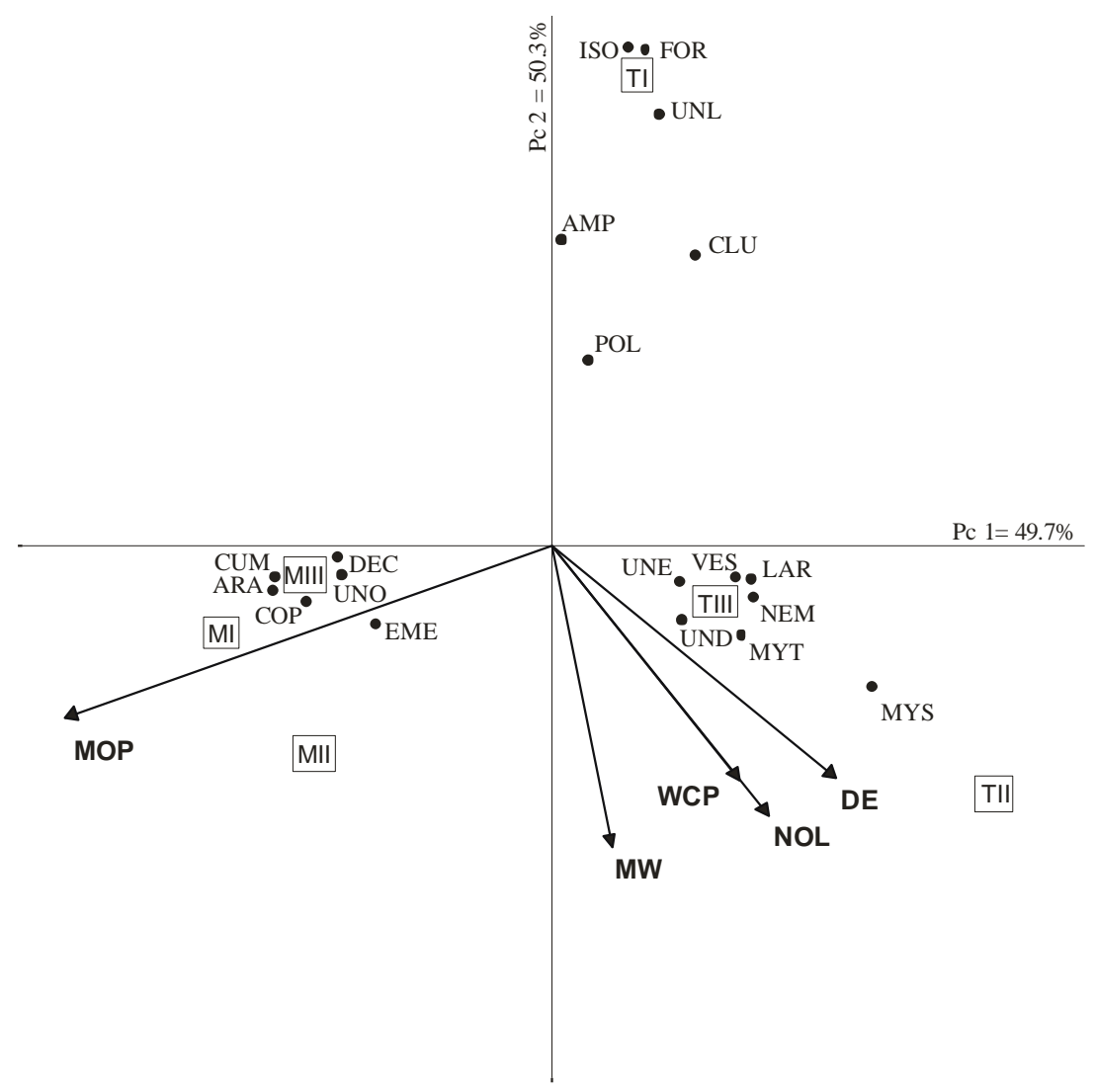

Fig. 5. Canonical Correlation Analysis of food items and morphometric measurements of Trachinotus carolinus (T) and Menticirrhus littoralis (M) by size class (I, II, III). (MOP) Position of the mouth, (MW) Maximum width, (WCP) Width of the caudal peduncle, (NOL) Nose open length, (DE) Diameter of the eye. 
The presence of some planktonic food items in the diet of $T$. carolinus and only benthic items in the diet of $M$. littoralis, suggests that despite the similarities, both species are probably feeding in different strata of the water column. Also, the terminal position of the mouth of $T$. carolinus and the subterminal position in $M$. littoralis, are an indication of how these species catch their prey within the surf zone.

Strong wave action is one of the physical factors that control sandy beach communities, because of the frequently disturbed unconsolidated sediment of these localities (McLACHLAN, 1990). The ability to burrow rapidly in this type of sediment is very important for the success of the species that inhabit the swash zone (DUGAN et al., 2000). According to some studies on burrowing efficiency, crabs of the super family Hippoidea (e.g. Emerita spp.) and misids are very good and fast burrowers in the swash zone of sandy beaches (NEL et al., 1999; DUGAN et al. 2000; BORZONE et al., 2007). This means that they can be found both in the water column and in the substrate. This high breaking wave energy, which is responsible for resuspending a large amount of sediment, easily dislodges polychaetes that adhere to the substrate up into the water column, so that they thus become a prey available to some pelagic fishes (DOMENICO et al., 2009).

MONTEIRO-NETO and CUNHA (1990) observed that $T$. marginatus swimming in the shallow water surf and the swash zone, fed on benthic prey (e.g., Emerita brasiliensis and Donax hanleyanus) lifted from the sediment into the water column, which appears to be the case of $T$. carolinus in the present study. Moreover, our study has shown that $M$. littoralis feed almost exclusively on bottom dwellers, thus presenting the typical demersal feeding mode of Sciaenidae (ZAHORCSAK et al., 2000).

The position of the mouth and the nose open length have further corroborated the hypothesis of distinct feeding niches. FUGI et al. (2001) found these morphometrics important to explain the diet patterns of five benthivore teleosts. These characteristics are linked with the type of growth exhibited by each species. M. littoralis shows a marked increase in body length resulting in an elongated ventrally depressed body enabling the species to swim, hover and even rest on the bottom, thus facilitating benthic feeding. $T$. carolinus, on the other hand, shows a greater growth in height, resulting in a compressed body which increases maneuverability. A narrow caudal peduncle and furcated caudal fin provide the necessary tools for fast swimming in the surf zone, making active swimming for feeding in the shallow water column possible.

Studies show the influence of morphology on the feeding of different species of teleosts (FUGI et al., 2001; WARD-CAMPBELL et al., 2005; RUSSO et al., 2007; TEIXEIRA; BENNEMANN, 2007). In this study, the two species fed primarily on small crustaceans and polychaetes, but different morphological traits have led to a divergent feeding mode to maximize the use of similar resources, reducing interspecific competition.

\section{ACKNOWLEDGMENTS}

We wish to thank A.G. Annes and M.S. Morasche for providing the specimens for this analysis and R.A. Tubino for his help with the stomach content analysis. Members of the ECOPESCA Laboratory helped in many aspects of this project. The CNPq provided fellowships for the authors and financial support for the completion of this study.

\section{REFERENCES}

AMUNDSEN, P. A.; GABLER, H. M.; STALDVIK, F. J. A new approach to graphical analysis of feeding strategy from stomach contents data - modification of the Castello (1990) method. Journal of Fish Biology, v. 48, p. 607-614, 1996.

BATISTIC, M.; TUTMAN, P.; BOJANIC, D.; SKARAMUCA, B.; KOZUL, V.; GLAVIC, N.; BARTULOVIC, V. Diet and diel feeding activity of juvenile pompano (Trachinotus ovatus) (Teleostei: Carangidae) from the southern Adriatic, Croatia. Journal of the Marine Biological Association of the United Kingdom, vol. 85, p. 1533-1534, 2005.

BELLINGER, J. W.; AVAULT, J. W. J. Food habits of juvenile pompano, Trachinotus carolinus, in Louisiana. Transactions of the American Fisheries Society; 100:486-494, 1971.

BORZONE, C. A.; LORENZI, L.; CALIL, P. Cross - Shore Mysydacea (Crustacea) Distribution on two sandy beaches with contrasting morphodynamics. Revista Brasileira de Zoologia. V. 24, n. 4, p. 943-949, 2007.

CAILliET, G. M.; LOVE, M. S.; EBELING, A. W. Fishes: a field and laboratory manual on their structure, identification, and natural history. Wadsworth, Inc, Belmont, California, 194 p, 1986.

CASATTI, L.; ROCHA, F., C.; PEREIRA, D. C. Habitat use by two species of Hypostomus (Pisces, Loricariidae) in southeastern Brazilian streams. Biota Neotropica, v. 5, n. 2, p. 1-9, 2005.

COSTA, C.; CATAUDELLA, S. Relationship between shape and trophic ecology of selected species of Sparids of the Caprolace coastal lagoon (Central Tyrrhenian sea). Environmental Biology of Fishes, v. 78, p. 115-123, 2007.

CUNICO, A. M.; AGOSTINHO, A. A. Morphological patterns of fish and their relationships with reservoirs (?reservoir) hydrodynamics. Brazilian Archives of Biology and Technology, v. 49, p. 125-134, 2006.

DELARIVA, R. L.; AGOSTINHO, A. A. Relationship between morphology and diet of six neotropical loricariids. Journal of Fish Biology, v. 58, p. 832-847, 2001. 
DOMENICO, M. D.; DA CUNHA LANA, P.; GARRAFFONI, A. R. S. Distribution patterns of intersticial polychaetesin Sandy beaches of southern Brazil. Marine Ecology, v. 30, p. 47-62, 2009.

DUGAN, J. E.; HUBBARD, D. M.; LASTRA, M. Burrowing abilities and swash behavior of three crabs, Emerita analoga Stimpson, Blepharipoda occidentalis Randall, and Lepidopa californica Efford (Anomura, Hippoidea), of exposed sandy beaches. Journal of Experimental Marine Biology and Ecology, v. 255, p. 229-245, 2000.

FERREIRA, K. M. Biology and ecomorphology of stream fishes from the Rio Mogi-Guaçu basin, Southeastern Brazil. Neotropical Ichthyology, v. 5, n. 3, p. 311-326, 2007.

FERRY, L. A.; CLARK, S. L.; CAILLIET, G. M. Food habits of spotted sand bass (Paralabrax maculatofasciatus, Serranidae) from Bahia de Los Angeles, Baja California. Southern California Academic of Sciences, v. 96, n. 1, p. 1-21, 1997.

FIGUEIREDO, J. L.; MENEZES, N. A. Manual de peixes marinhos do sudeste do Brasil, IV teleostei (3). Museu de Zoologia, Usp, São Paulo, 1980. 96 p.

FUGI, R.; AGOSTINHO, A. A.; HAHN, N. S. Trophic morphology of five benthic-feeding fish species of a tropical floodplain. Revista Brasileira de Biologia, $v$. 61, n. 1, p. 27-33, 2001.

HELMER; J. L.; TEIXEIRA, R. L.; MONTEIRO-NETO, C. Food habits of young Trachinotus (Pisces, Carangidae) in the inner surf-zone of a sandy beach in southeast Brazil. Atlântica, v. 17, p. 95-107, 1995.

KAWAKAMI, E.; VAZZOLER, G. Método gráfico e estimativa de índice alimentar aplicado ao estudo de alimentação de peixes. Boletim do Instituto Oceanográfico, São Paulo, v. 29, n. 2, p. 205-207, 1980.

LAMEIRO, F. R.. Relações tróficas de Menticirrhus americanus (Linaeus, 1758) e Menticirrhus littoralis (Holbrook, 1855) na zona de arrebentação das praias arenosas adjacentes a barra do Rio Grande, RS. Brasil. Master's thesis, Fundação Universidade Federal do Rio Grande, 2003. 104 p.

LEGENDRE, P.; LEGENDRE, L. Numerical ecology: Developments in environmental modelling 20. $2^{\text {nd }}$. ed. Elsevier Science BV, Amsterdam, 1998. 853 p.

McCORMICK, M. I. Fish feeding on mobile benthic invertebrates: influence of spatial variability in habitat associations. Marine Biology, v. 121, p. 627-637, 1995.

McLACHLAN, A. Dissipative beaches and macrofauna communities on exposed intertidal sands. Journal of Coastal Research, n. 6, p. 57-71, 1990.

McMICHAEL, R. H. JR; ROSS, S. T. The relative abundance and feeding habits of juvenile kingfish (Sciaenidae: Menticirrhus ) in a Gulf of Mexico surf zone. Northweast (Northeast or Northwest?) Gulf Science, n. 9, v. 2, p. 109-123, 1987.

MIGDALSK, E. C.; FISHER, G. S. The fresh and salt water fishes of the world. Greenwich House, New York, $1976.316 \mathrm{p}$

MODDE, T. Growth and residency of juvenile fishes within a surf zone habitat in the Gulf of Mexico. Research Reports, v. 6, n. 4, p. 377-385, 1980.

MODDE, T.; ROSS, S. Seasonality of fishes occupying a surf zone habitat in the northern Gulf of Mexico. Fishery Bulletin, v. 78, n. 4, p. 911-922, 1981
MONTEIRO-NETO, C; CUNHA, L. P. R. Seasonal and ontogenetic variation in food habits of juvenile Trachinotus marginatus Cuvier, 1832 (Teleostei, Carangidae) in the surf zone of Cassino beach, RS, Brazil. Atlântica, v. 12, n. 1, p. 45-54, 1990.

MONTEIRO-NETO, C.; CUNHA, L. P. R.; MUSICK, J. A. Community structure of surf-zone fishes at Cassino beach, Rio Grande do Sul, Brazil. Journal of Coastal Research, v. 35, p. 492-501, 2003.

MONTEIRO-NETO, C; TUBINO, R. A.; MORAES, L. E. S.; MENDONÇA-NETO, J. P.; ESTEVES, G. V.; FORTES, W. L. Associações de peixes na região costeira de Itaipu, Niterói, RJ. Iheringia, Série Zoologia, v. 98, n. 1, p. 50-59, 2008.

MOTTA, P. J.; KOTRSCHALL, K. M. Correlative, experimental, and comparative evolutionary approaches in ecomorphology. Netherlands Journal of Zoology., v. 42, p. 400-415, 1992.

MOTTA, P. J.; CLIFTON, K. B.; HERNANDEZ, P.; EGGOLD, B. T.; GIORDANO, S. D.; WILCOX, R. Feeding relationship among nine species of seagrass fishes of Tampa Bay, Florida. Bulletin of Marine Science, v. 56, n. 1, p. 185-200, 1995.

NEL, R., MCLACHLAN, A., WINTER, D. The effect of sand particle size on the burrowing ability of the beachmysid, Gastrosaccus psammodytes Tattersall. Est. Coastal Shelf Science, n. 48, p. 599-604, 1999.

NELSON, W. G. Predation and prey population variation in a high energy sand beach macrofaunal community. Ophelia, v. 26, p. 305-316, 1986.

PETERS, D. J.; NELSON, W. G. The seasonality and spatial patterns of juvenile surf zone fishes of the Florida east coast. Florida Science, v. 50, n. 2, p. 79-84, 1986.

ROSS, S. W.; LANCASTER, J. E. Movements and site fidelity of two juvenile fish species using surf zone nursery habitats along the southeastern North Carolina coast. Environmental Biology of Fishes, v. 63, p. 161172, 2002.

ROSS, S. T.; MCMICHAEL JR., R. H.; RUPLE, D. L. Seasonal and diel variation in the Standing crop of fishes and macroinvertebrates from a Gulf of Mexico surf zone. Estuarine, Coastal \& Shelf Science, v. 25, p. 391-412, 1987.

ROSS, S. T.; McMICHAEL, R. H. J. The relative abundance and feeding habits of juvenile kingfish (Sciaenidae: Menticirrhus ) in a Gulf of Mexico surf zone. Northeast Gulf Science, v. 9, n. 2, p. 109-123, 1987.

RUSSO, T.; COSTA, C.; CATAUDELLA, S. Correspondence between shape and feeding habit changes throughout ontogeny of gilthead sea bream Sparus aurata L., 1758. Journal of Fish Biology, n. 71, p. 629-656, 2007.

SALOMAN, C. H.; NAUGHTON, S. P. Fishes of the littoral zone Pinellas county, Florida. Biology and Sciences, v. 42, n. 2, p. 85-93, 1979.

SCHAFER, L. N.; PLATELL, M. E. VALESINI, F.J.; POTTER, I.C. Comparisons between the influence of habitat type, season and body size on the dietary compositions of fish species in the nearshore marine waters. Journal Experimental Marine Biology and Ecology, v.278, p. 67-92, 2002.

TEIXEIRA, I.; BENNEMANN, S. T. Ecomorfologia refletindo a dieta dos peixes em um reservatório no sul do Brasil. Biota Neotropica, v. 7, n. 2, p. 67-76, 2007. 
TER BRAAK, C. J. F.; SMILAUER, P. CANOCO Reference Manual and User's Guide to Canoco for Windows: Software for Canonical Community Ordination (version 4). Microcomputer Power (Ithaca, NY, USA), 1998 $352 \mathrm{pp}$.

VASCONCELLOS, R. M; SANTOS, J. N. S; SILVA, M. A.; ARAÚJO, F. G. Efeito do grau de exposição às ondas sobre a comunidade de peixes juvenis em praias arenosas do Município do Rio de Janeiro, Brasil. Biota Neotropica, v. 7, n. 1. p. 93-100, 2007.

WARD-CAMPBELL, B. M. S.; BEAMISH, F. W. H. KONGCHAIYA, C. Morphological characteristics in relation to diet in five coexisting Thai fish species. Journal of Fish Biology, v. 67, p. 1266-1279, 2005.
WHEELER, K. N.; STARK, C. C.; HEARD, R. W. A preliminary study of the Summer feeding habits of juvenile Florida panpano (Trachinotus carolinus) from open and protected beaches of the northeastern Gulf of Mexico. 53rd Gulf and Caribbean Fisheries Institute, p. 659-673, 2002.

ZAHORCSAK, P.; SILVANO, R. A. M.; SAZIMA, I. Feeding biology of a guild of benthivorous fishes on a sandy shore on south-eastern Brazilian coast. Revista Brasileira de Biologia, v. 60, n. 3, p. 511-518, 2000.

(Manuscript received 04 June 2009; revised 02 October 2009; accepted 06 November 2009) 